\title{
Persepsi Siswa Terhadap Pelayanan Pegawai Tata Usaha di SMK Negeri 1 Kecamatan Guguak Kabupaten Lima Puluh Kota
}

\author{
Fatma Wila ${ }^{1}$, Hadiyanto $^{2}$, Rifma $^{3}$, Lusi $^{4}$ \\ 1,2,3,4 Administrasi Pendidikan, Universitas Negeri Padang
}

Fatma Wila ${ }^{1}$, e-mail: fatmawila9604@gmail.com

Hadiyanto $^{2}$, e-mail: hadiyanto@fip.unp.ac.id

Rifma ${ }^{3}$, e-mail: rifmar34@gmail.com

Lusi ${ }^{4}$, e-mail: lusy_mp@yahoo.com

\begin{abstract}
This existance of problems that the reseachers encountered in Vocationl High School 1, Guguak District, Lima Puluh Kota District related to administrative staff service that were still not optimal was the background of this study, so that were still students who were not satisfied with the services received by these pupils. The purpose of this study is to describe student's perceptiions of administrative staff services in terms of transparency, reliability, responsiveness, and physical evidence. The type of this research is descriptiive usiing a quantiitative approoach. Data were collected using a questionnaire, the data sources in this study were all students and female students in the Vocational High School 1, Guguak District. The results showed that : 1) students perceptions of administrative staff services in Guguak District 1 Vocational High School, seen from the transparancy aspect, were good with an average score of 3,94,2) Student's perceptions of administrative staff services in Public Vocational High School 1 Guguak Subdistict, seen from the reliability aspect, is good with an average score of 3,94,3) Student's perceptions of administrative staff services at the Vacational High School 1, Guguak District, seen from the responsiveness aspect, are good with an average score of 4,20. 4) Student's perceptions of administrative staff service in Vocational High School 1, Guguak District, seen from the aspect of physical evidence it is goods with an average score of 4,13,5) Student's perceptions of administrative staff services in Public Vocational High School 1, Guguak Subdistrict, Lima Puluh Kota Regency is already good with an average score of 4,11 .
\end{abstract}

Keywords: Services, Administrative Staff

\begin{abstract}
Abstrak
Adanya permasalahan yang peneliti temui pada Sekolah Menengah Kejuruan Negri 1 Kec. Guguak Kab. 50 Kota terkait pelayanan pegawai tata usaha yang masih kurang optimal menjadi latar belakang dari penelitian ini, sehingga masih ada siswa yang kurang puas terhadap pelayanan yang diterima oleh siswa tersebut. Penelitian ini bertujuan menggambarkan perception pupils terhadap pegawai administrative dilihat dari aspek transparansi, reliabelitas, responsivitas, dan bukti fisik. Adapun bentuk penelitian ini merupakan deskriptif menggunakan pendekatan quantitatiff. Data dikumpulkan menggunakan quesioner, data dalam penelitian ini menggunakan subjek seluruh siswa/i di Sekolah Menengah Kejuruan Negri 1 Kec. Guguak Penelitian ini menghasilkan bahwa : 1) perception of students pada layanan pegawai TU di SMK Negri 1 Kec. Guguak ditinjau dari aspek transparan sudah baik memiliki skor rata-rata 3,94, 2) persepsi siswa terhadap pelayanan pegawai tata usaha di SMK Negri $1 \mathrm{Kec}$. Guguak dilihat dari aspek reliabelitas memiliki skor rata-rata 4,18, 3)persepsi siswa terhadap pelayanan pegawai tata usaha di SMK Negri 1 Kec. Guguak ditinjau dari aspek responsivitas sudah baik memiliki rata-rata 4,20,4) persepsi siswa terhadap pelayanan pegawai tata usaha di SMK Negri 1 Kec. Guguak ditinjau dari aspek bukti fisik sudah baik memiliki rata-rata 4,13, 5) persepsi siswa terhadap pelayanan pegawai tata usaha di SMK Negri 1 Kec. Guguak Kab. Lima Puluh Kota sudah baik memiliki rata-rata 4,11 .
\end{abstract}

Kata Kunci: Pelayanan, Pegawai Tata Usaha.

How to Cite: Fatma Wila 1, Hadiyanto 2, Rifma 3, Lusi 4. 2020. Persepsi Siswa Terhadap Pelayanan Pegawai Tata Usaha di SMK Negeri $1 \mathrm{Kec}$. Guguak, Kab. Lima Puluh Kota. Journal Educational Administration and Leadership, Vol (N): pp. XX-XX, DOI:10.24036/XXXXXXXXXX-X-XX 


\section{Pendahuluan}

Sumber daya manusia adalah suatu bagian yang penting dalam pencapaian organisations. Manusia sebagai sumber daya manusia yang handal dan memiliki keahlian sangat dibutuhkan dalam menghadapi tuntutan jaman. Di suatu organisasi SDM itu dipersiapkan untuk mencapai tujuan organisasi serta memperluas karir yang terkait di lingkungan kerja. SDM memiliki kedudukan terpusat kareena bertugas dalam meningkatkan efektif serta efisien suatu organisations.

Sumber daya manusia sangat dibutuhkan di seluruh lembaga mencakup lembaga pendidikan termasuk sekolah. Untuk mewujudkan goals school's, diperlukan keahlian dan keterampilan yang baik dari seluruh komponen yang berperan penting. Tata Usaha adalah suatu bidang yang berperan penting dalam mengerjakan administrative of school yang dibutuhkan untuk mencapai tujuan pendidikan.

Aturan Kepegawaian (Perrmendiknas No 24/ 2008) menjelaskan bahwa pekerjaan petugas administrative sekolah di tingkat pendidikan SD hingga menengah tdk boleh dirapel oleh tenaga fungsiional lainnya. Selaku subsystem peembelajaran, akan saling berkaitan dengan komponen lainnya supaya tujuan pendidikan dapat dicapai sesuai dengan harapan. Subsystem harus dipenuhi criteria, baik dari segi kuantitas dan kualitasnya sesuai dengan standar nasional pendidikan sehingga hasilnya sesuai dengan tujuan pembelajaran di setiap satuan pendidikan dapat dicapai sesuai rencana strategis yang ditetapkannya.

Dalam menghandle tata usaha sekolah diperlukan keahlian serta keterampilan memadai di bagian administrasi adalah punya skill,handal, dan mengerti job desc nya. Komponen tenaga administrasi sekolah memberikan kontribusi terhadap iklim sekolah, juga pada aliansi mempengaruhi kualitas pendidikan di sekolah (Hadiyanto 2016). Tata Usaha sekolah dilakukan dan berkelanjutan.

Berdasarkan observasi peneliti selama melakukan Praktek Lapangan Kependidikan (PLK) pada tanggal -09 Juli samapai 09 November 2019 di SMK Negri 1 Kec. Guguak, system pengelolaan tata usaha di SMK Negri $1 \mathrm{Kec}$. Guguak sudah menggunakan system computerisasi, mulai dari pencatatan serta pengelolaan data. Masalah yang ditemukan di ketatausahaan sekolh tersebut adalah adanya kesalahpahaman yang sering terjadi antara pegawai tata usaha dengan siswa dalam menyampaikan informasi, keluhan siswa yang kurang cepat ditanggapi oleh pegawai tata usaha sehingga siswa tidak puas terhadap pelayanannya, masih kurang ramahnya pegawai tata usaha kepada siswa. Kemudian maih adanya sebagian siswa yang belum merasakan kenyamanan atas pelayanan yang diberikan pegawai tata usaha . Masalah ini terjadi karena belum lengkapnya fasilitas yang ada di tata usaha.

Penelitian ini bertujuan untuk mendeskripsikan persepsi siswa/i pada pelayanan tata usaha di SMK Negri 1 Kec. Guguak, Kab. 50 Kota dilihat dari aspek transparansi,reliabelitas,responsivitas, dan bukti fisik.

\section{2. Metode Penelitian}

Jenis penelitian ini adalah deskriptif menggunakan pendeekatan kuantitatif, data research ini mengenai persepsi siswa/i tentang layanan petugas administrative di SMK Negri $1 \mathrm{Kec}$. Guguak yang di sajikan dalam model angka-angka dan dianalysis dengan metode statistik. Penelitian ini dilakukan di SMK Negri 1 Kec. Guguak, Kab. 50 Kota, seluruh siswa dan siswi di sekolah tersebut adalah subject penelitiannya. Angket yang difungsikan dalam instrumen this research is quisioner. (Ariikunto 2010) mengatakan jika insstrumen penelitian merupakan fasilitas yg difungsikan oleh peneliti pada mengumpulkan data agar tugsnya lebih simple dan outputnya lebih good, dalam arti yg lebih teliti, full, serta berurutan sehingga lebih mudah dikerjakan. Pada penelitian ini instrumen yang digunakan adalah kuesioner atau angket yang disebar kepada siswa di SMK Negeri 1 Kecamatan Guguak. Angket yang disediakan adalah angket tertutup dimana answer sudah tersedia dan responden hanya memilih dari jawaban yang disediakan. Karena dalam masa pandemi Covid-19, maka angket dibagikan dalam bentuk angket online. Semua siswa hanya mengisi angket dari ponsel masing-masing. 


\section{3. Hasil dan Pembahasan}

Persepsi merupakan pandangan tentang suatu objek dalam menginterperensikan dan mengorganisasikan sebuah karya sehingga memiliki arti dalam lingkungan terkait dengan objek yang sama. Thoha, (2012 : 141 ) mengemukakan bahwa persepsi merupakan proses kognitiff yang setiap orang mengalaminya didalam memahami information mengenai lingkungannya baik lewat pengliihatan, pendeengaran, pengahayatan, perasaaan dan penciiuman. Selanjutnya Rivai (2012:326) mengatakan persepsions ialah suatu procees yang di tempuh seseorang dalam mengoperasikan dan mengisyaratkan kesan-keesan indra yang memberi makna. Selain itu Wiibowo (2015:59) mengatakan persepsions merupakan suatuu proceees seseorang mengelola serta menginterprestasikan kesan mereka dalam tujuan memberi makna pada lingkungan mereka.

Dari pengertian menurut para pakar diatas, sehigga dapat suatu kesimpulan bahwa persepsi merupakan suatu penglihatan dan pemikiran serta penilaian seseorang tentang suatuobjek sehingga melahirkan sebuah anggapan atau penafsiran. Dalam penelitian ini adalah sebuah pandangan, tanggapan dan pendapat terhadap pelayanan yang dilakukan oleh petugas administrative di SMK Negeri 1 Kecamatan Guguak.

Kegiatan seseorang atau segerombolan organisations secara langsung maupun tidak langsun dalam pemenuhan keperluan biasanya disebut sebagai services. (Moenir 2010) menyatakan "services merupakan process memenuhi keperluan lewat other people activity secara langsuung". Wareella in (Pasoolong, 2010) menjelaska bahwa pelayanan (service) merupakan suatu perbuatan (deed), suatu performa atau suatu effort . Gronroos dalam (Pasolong, 2010) menyatakan services ialah serangkaian aktivitas yang bersifat tidak terlihat terjadi karena hubungan timbal balik sesama konsument serta peegawai atau hal lainnya yang dipersiapkan oleh organisations give serices yang dimaksudkan untuk menyelesaikan kendala konsumen . Kemudian (Tjiptono 2012) menyebutkan bahwa services merupakan penyediaan, aktivitas, dan informtionsi yang diberikan dalam menaikkan kahlian konsumen dalam mewujudkann niilai potensiial yang ada di produk yg dibelii konsumen. Sedangkan (Daryanto and Budi 2014) mengatakan pelayanan merupakan segala aktivitas yang mendapatkan untung di suatu kesatuan, serta mendapatkan hasil yang puas meski hasilya belum melekat di suatu produk secara fisik. Jadi diambil kesimpulan services adalah suatu proses harus dikerjakan untuk memenuhi kebutuhan pelanggan dengan bentuk penyajian, tindakan dan informasi yang diberikan.

(Dwiyanto 2012) menyebutkan bahwa dalam indikator pelayanan ada standar pelayanan publik yaitu input, proses dan output. Input distandarisasi sangat diperlukan untuk meningkatkan pelayanan. Perumusan standart process saat dijamin layanan public in area dipenuhi prinsip2 pelaksana layanan yang transparans, nonpartiisipan, efesiensi serta akuntabell. Standart yang difungsikan dalam mengamati pelayanan yang diberikan dapat dipenuhi standart yg sudah ditentukan ataukah disebut dengan keluaran/hasil. Keputusan Menteri Pendayagunaan Aparatur Negara No. 58 Thn 2002 memiliki 7 elemen yang dapat dijadikan sebagai pondasi dalam ukuran skill layanan public intansi pemerintahan dan BUMN, ke7 elemen layanan public tersebut ialah sbb: a) pelayanan dilakukan dengan prosedur yang sederhana, b) information of services yang terbuka, c) pelayanan dilaksanakan yang pasti, d) mutu layanan, e) profesioanalitas pegawai, f) administrasi yang dikelola dengan tertib, g) fasilitas services yang lengkap.

Dalam mencapai tujuan pendidikan di sekolah biasanya pelayanan dilakukan oleh pegawai tata usaha. TU adalah administrative ialah segala pekerjaan megumpulkan, menyatat, memproses, merangkap, menyiimpan data /informasi tentang objek tertentu dengan berkelanjutan serta berurutan dalam suatu maksud. (Rivai, 2004:151) mengatakan bahwa Tata usaha adalah bagian semua proses administrasi . Tenaga TU adalah pegawai kependidkan yg kerjanya lebih dituntut keahlian tekniis administrative. Berdasarkan uraian diatas, bisa diambil kesimpulan jika tata administrative adalah pekerjaan memberi bantuan dalam me manage informas human kearah tujuan yg ada dalm organisasi.

Hasil dan pembahasan penelitian mengenai Persepsi Siswa/i Terhadap layanan Pegawai Tata Usaha SMK Negri 1 Kecamtan Guguak Kabupaten Lima Puluh Kota dapat dilihat dari masing- masing indikator yaitu: 3.1. Transparansi

Transparansi merupakan sifat keterbukaan, simple, dn dapat dijangkau olh orang yang terlibat dibutuhkan, menyediakan cukup serta mudah dimegerti. Transparansi dalam pelayanan akan 
meniingkatkan keperrcayaan yang timbal balik antara pegawai dn siswa dg ketersediaan informasi dn menjamin kemudahan dlm memperoleh good information dn akurat.

Berdasarkan hasil angket atau kuesioner yang dibagikan kepada siswa ,maka transparansi dari pelayanan pegawai tata usaha di Sekolaah Meenengah Kejuruan Negri 1 Kecaamatan Guguak dapat dikatakan baik memiliki nilai rata-rata 3,94 .

3.2. Reliabelitas

Reliabelitas merupakan suatu kemampuan dalam melayani jasa sesuai dengan yang disepakati, terpercaya dan tepat, dan konsisten. Reliabelitas memiliki dua bagian utama yaitu konsistensi kinerja dan sifat terpercaya .

Dalam (Keputusan Menterii Pendaayagunaan Aparatur Negara 2002) menjelaskan jika pelaksanaan services yang pasti yaitu mencakup time action dn biaya, apakh waktuu yg diperlukan dlm layanan diberikan sesuai dengan jadwalnya, serta apa biaya yang dibayar oleh konsumen sama dg biaya yg ditetapkan. Jadwal pelayanan yg pasti ini berkaitan dengan disiplin time petugas pelayanan .

Berdasarkan hasil penelitian yang didapatkan dari persepsi siswa terhadap pelayanan pegawai tata usaha dilihat dari aspek reliabelitas sudah baik dengan skor rata-rata 4,18.

3.3. Responsivitas

Responsivitas yaitu penyediaan dan melayani para pelanggan dalam memberi bantuan dan melakukan layanan para pelanggan dengan tanggap. Berikut ini adalah contohnya antara lain : ketepatan waku services, bukti transaksi dikirim cepat, tanggap jika dihubungi konsumen, dan layanan disampaikan secara cepat.

( KEPMEN Nomor 58 Tahun 2002) menjelaskan bahwa kualitas dari services terdiri dari proses layanan, cepatkah, apa hasil nya bagus tersusun sistematis atau sebaliknya. Kecepatan pelayanan adalah waktu target dan layanan bisa selesai saat time sudah ditetapkan sama unit penyelenggara services. Cepatnya pegawai dalam memberikan services kepada msyaarakat berkaitan with disiplin times dari petugas itu sendiri.

Hasil pengumpulan data dan pembahasan tentang persepsi siswa terhadap pelayanan pegawai tata usaha dilihat dari aspek responsivitas adalah baik dengan rata-rata skor 4,20.

\subsection{Bukti Fisik (Tangibles)}

Bukti fisiik, termasuk with daya tarik fasilitas, dan material yang difungsikan oleeh perusahaan , dan kepribadian pegawai. (KEPMEN No 58 Tahun 2002) menjelaskan bahwa saranaa dan prrasarana merangkap wujud dan fungsinya, tidak penampilan tapi sampai dimana kegunaan dari sarana fasalitas tsbt dapat mempermudah, kelancaran seluruh process layanan serta pemberi kenyaman bagi pemakai layaanan.

(Moenir 2010) menjelaskan bahwa saraana pellayanan merupakan semua alat-alat, kelengkapan pekerjaan serta sarana lainnya yg berguna untuk alat bantu pada pelaksanakan kerja, serta berguna untuk khalayak ramai terhadap keperluan manusia yang sedang berkaitan dg organisations pekerjaaan itu.

Kegunaan dari saraana pelayaanan adalah sebagai berikut :

1) Proses kegiatan, dpat mempersingkat waktu menjadi lebih cepat.

2) Produktivitas, berupa produk atau jasa meningkat.

3) Hasil menjadi lebh baik.

4) Urutan dn stability ukuran terjaga dan tepat.

5) Mempermudah gerak perilakunya.

6) Munculnya rasa kenyamanan bagi orang-orang yg membutuhkan.

Rasa puas yang muncul pada orang yg berkepentingan dapat meminimalisir emosi nya.

Hasil pengumpulan data yang di peroleh bahwa persepsi siswa terhadap pelayanan pegawai TU dilihat dari aspek bukti fisik adalah baik dengan score average 4,13. 
Fatma Wila $^{1}$, Hadiyanto ${ }^{2}$, Rifma $^{3}$, Lusi $^{4}$ Persepsi Siswa Terhadap Pelayanan Pegawai Tata Usaha di SMK Negeri 1 Kecamatan Guguak Kabupaten Lima Puluh Kota

\section{4. Kesimpulan}

Dapat disimpulkan terkait persepsi siswa/i pada layanan petugas TU SMK Negri 1 Kecamatan Guguak Kabupaten Lima Puluh Kota ditinjau oleh masing- masing indikator yang dijabarkan sebagai berikut:

\subsection{Transparansi}

Terkait transparansi dari persepsi murid SMK Negri 1 Kec. Guguak terhadap pelayanan pegawai tata usaha adalah baik.

4.2. Reliabelitas

Kesimpulan dari hasil dan pembahasan terkait reliabelitas layanan petugas TU di Sekolah Menengah Kejuruan Negri 1 Kec. Guguak adalah baik .

4.3. Responsivitas

Terkait responsivitas dari persepsi siswa/i pada layanan petugas TU Sekolah Menengah Kejuruan Negri 1 Kec. Guguak adalah baik.

\subsection{Bukti Fisik}

Persepsi siswa pada pelayanan pegawai tata usaha di Sekolah Menengah Kejuruan Negri 1 Kec. Guguak terkait bukti fisik adalah baik.

4.5. Secara umum persepsi siswa pada layanan petugas TU Sekolah Menengah Kejuruan Negri 1 Kec. Guguak Kab. 50 Kota sudah baik.

\section{Daftar Rujukan}

Arikunto. 2010. Prosedur Penelitian Satuan Pendekatan Praktik. .Jakarta: PT.Rineka Cipta.

Daryanto,. dan Ismanto Setya Budi. 2014. Konsumen Dan Pelayanan Prima. Yogyakarta: Gava Media.

Dwiyanto, Agus. 2012 . Manajemen Pelayanan Publik: Peduli, Inkusi Dan Kolaboratif. Yogyakarta: Gajah Mada University Press.

Hadiiyanto. 2016. Teori Pengeembangan Ikliim Kelas/ class \& Iklim Sekolah. Jakarta: Kencana.

Keputusaan Mentri Pendyagunaan Aparratur Negara. 2002. Nomor 58 Tentang Pedoman Pelaksanaan Penilian Dn Penghargaan Citra Pelayanan Prima.

Moeenir, A. 2010. Manajement Pelayanan Umuum di Indonesia. Jakarta: Bumi Aksara.

NEGARA, KEPMEN. 2002. “KEPMEN NO.58.” Pedoman Pelaksanaan Penilian dan Penghargaan Citra Pelayanan Prima.

Pasolong, Harbani. 2010. Kepemimpinan Birokrasi. Bandung: AlfaBeta.

Pasoloong. 2010. Teori Administrasi Public. Bandung: Alfabeta.

Permendiknas. 2008 . "Badan Kepagawaian.” No 24.

Rivai. 2004. Kepemimpinan Dan Perilaku Organisasi. Jakarta: PT.Raja Grafindo.

Riivai, Dkk. 2013. Kepemimpinaan dan Prilaku Organisation. Jakarta: PT Raja Grafindo.

Thooha, Muhammad. 2012. Prilaku Organisasition Konsep Dasar dan Aplikasiinya. Jakarta: PT.Raja Grafiindo. Tjiptono, Fandi. 2012. Servicee Managemennt Mewujudkan Pelayanan Prima. Yogyakarrta: Andi. 